\title{
W perspektywie Innego. Czytanie opowiadań Irit Amiel w kontekście psychologii międzykulturowej
}

Zacznijmy od pewnej żydowskiej anegdoty ${ }^{1}$. Rozmawia ze sobą dwóch chasydów. Jeden mówi drugiemu: „Czy ty mnie kochasz?”. Drugi odpowiada: „Tak, kocham cię”. Borys pyta go: „Wiesz, co sprawia, że cierpię?” A drugi odpowiada: „Jakże mogę wiedzieć, co sprawia ci cierpienie?”. Borys mówi: „Jeśli nie wiesz, co sprawia, że cierpię, jak możesz mówić, że mnie kochasz?”.

Nieprzypadkowo tę chasydzką anegdotę, przypisywaną Yechudzie Lejbowi z Sasowa, przytacza rabin David Rosen ${ }^{2}$ podczas wykonania symfonii katechetycznej Cierpienie Niewinnych skomponowanej przez Kiko Arguello w Auschwitz 23 czerwca 2013 roku. Próba zrozumienia tego, co wydarzyło się w obozach koncentracyjnych, wykracza zdecydowanie poza tradycyjne kategorie poznawcze. Za pytaniem Borysa kryje się bowiem zaproszenie - try walking in my shoes - do wejścia głębiej w relację z Innym, przyjęcia jego punktu widzenia.

\footnotetext{
${ }^{1}$ Dowody anegdotyczne zajmują poczesne miejsce w studiach nad odbiorem tekstów kultury. Są one „swoistą metaforą narracyjną, formą przypowieści, której przesłanie odnosimy do świata rzeczywistego, niczym znaczenie interpretowanego tekstu" (Maryl: 312-313). W tradycji żydowskiej „szmonces” czy anegdota pełnią funkcję mądrościową, odsyłając do egzystencjalnej warstwy znaczeniowej.

${ }^{2}$ Zapis wystąpienia: źródło filmowe, https://www.youtube.com/watch?v=qkcle-okZYI (49.10-50.20).
} 
W kontekście takiego zaproszenia warto spojrzeć na opowiadania Irit Amiel, która buduje opowieść o Zagładzie w relacji dyskursywnej. Amiel, wymieniana obok Idy Fink izraelska pisarka i poetka, jest przedstawicielką pokolenia ocalałych z Holocaustu. Michał Głowiński w „Posłowiu” (Głowiński: 103) do Osmalonych, tomiku opowiadań nominowanych w 2000 roku do Nagrody Nike, zauważa, że Irit Amiel jest pisarką jednego tematu, jednego doświadczenia. Jak sugeruje sam tytuł książki, Zagłada, która zakończyła się wraz z upadkiem hitlerowskich Niemiec, trwa w tych, którzy - podobnie jak sama autorka - ją przetrwali ${ }^{3}$. Można zatem czytać Osmalonych jako zapis zmagania się z traumą, która nie pozwala wrócić do normalności.

W piętnastu opowiadaniach Amiel koncentruje uwagę na ludziach, którzy ocaleli (by posłużyć się znaną Różewiczowską fraza), a zarazem noszą w sobie śmierć. Zagłada wciąż określa ich życie „tu i teraz” w scenerii Palestyny, dokąd wyjechali, czy Stanów Zjednoczonych, gdzie robią kariery. Tytułowe „osmalenie” nie da się usunąć żadnymi sposobami, jest niezmywalne. Zaproponowana przez izraelską pisarkę metafora odnosi się do śladu - tropu silnie powiązanego czasem i przeszłością. Barbara Skarga zauważa, że w przeciwieństwie do pamięci, ślad odnosi się do przeszłości w sposób emocjonalny i zaangażowany. Jest dowodem istnienia jakiejś przeszłości, która odcisnęła się w naszym życiu. Dlatego ślad domaga się powiązania ,jej z zespołem innych słów, takich, które przechowują przeżycia i doświadczenia egzystencjalne" (Skarga:76).

Kluczowym dla zrozumienia użytej przez autorkę metafory „osmalenie” wariantem śladu jest blizna. Blizna jest śladem zranienia, przeżytego bólu, o którym przypomina. Pomimo upływu czasu cierpienie często nie mija, ból trwa, przenosi wciąż w przeszłość, do wydarzenia, które ten ból stale uobecnia. Blizna nigdy nie ulega zatarciu. Ma zawsze charakter osobisty, silnie egzystencjalny, odnosi do tego, co przeżyło się samemu. Dlatego opowiadania Amiel są zapisem pojedynczych historii: Linki, Rafała, Klary, Noemi, Ziwy i innych. Ich bohaterowie doświadczają utraty, wygania, prześladowania, ale każde w inny, niepowtarzalny sposób. Jednocześnie te pojedyncze historie układają się we wspólne doświadczenie cierpienia - to, co osobnicze, staje się u Amiel

${ }^{3}$ Podczas II wojny światowej Amiel znalazła się w getcie częstochowskim, z którego uciekła. Jej rodzina zginęła w niemieckim nazistowskim obozie zagłady w Treblince. Ona sama przeżyła wojnę dzięki pomocy Polaków, którzy spreparowali dla niej fałszywe dokumenty. 
powszechne. Tylko jak opowiedzieć o tym, co wspólne, nie tracąc nic z tego, co jednostkowe?

Można odnieść ważenie, że autorka „w tych narracjach powściągliwych, skromnych, unikających słów wielkich i mocnych” (Głowiński: 106) szuka takiego języka. Jan Błoński, przywołany później przez Jacka Leociaka w Tekście wobec Zagtady, pisał :

Holokaust jest w istocie niemożliwy do opowiedzenia i cokolwiek o nim czytamy, nieuchronnie przeraża i rozczarowuje zarazem. Pióro łamie się pod ciężarem doświadczeń, co przekraczają ludzką miarę. Pisarz, w którego pamięci tkwią tak przerażające przeżycia, nie może się od ich oderwać i także - nad nim zapanować, nadając im wspólny (jednolity) kształt...

(Błoński, 1994: 103)

Wydaje się, że kategorią, za pomocą której Amiel stara się opisać tragedię Shoah, jest właśnie „osmaloność”. W opowiadaniach staje się ona tym wspólnym kształtem, w który wpisują się poszczególne historie bohaterów. Zakorzenienie postaci w różnych tradycjach oraz powojenne zmieszanie kulturowe, wynikające z przymusowych migracji, jeszcze bardziej uwydatnia indywidualność losów, a tym samym utrudnia zrozumienie wspólnotowości doświadczenia.

$\mathrm{Na}$ tych różnicach Amiel buduje swoją narrację. W opowiadaniach Wspótczesny splot czy z Izraelskiego tygla autorka konstruuje opowieść złożoną z głosów poszczególnych postaci. Bohaterowie jej opowiadań przyjeżdżają do Tel Awiwu, Indii, Holandii albo Nowego Jorku, mówią po rosyjsku, polsku, włosku, słabo po hebrajsku. Żyją w Palestynie, ale wszyscy są przyjezdnymi z Cypru, Włoch, Polski, Niemiec. Jednego z nich autorka scharakteryzuje następująco: „Nazywał się Palestyńczyk, wyglądał jak Cygan, a był izraelskim Żydem z Polski” (Amiel: 26).

Można przypuszczać, że w analizie opowiadań pomocne będą studia kulturowe ${ }^{4}$ (Barker, 2005) wraz z analizą transkulturową (Pratt, 1992), badającą przestrzeń pogranicza kulturowego, w którym dokonuje się selekcja i przenoszenie elementów z jednej do drugiej kultury (hegemonicznej do mniejszościowej i odwrotnie), oraz wszelkiego rodzaju badania nad tożsamością i czynnikami,

${ }^{4}$ Postulowane podejście kulturowe uznaje literaturę za jedną z praktyk komunikacyjnych, za pomocą której konstytuuje się dyskurs społeczny i kształtuje się postawy podmiotów biorących udział w konstruowaniu społecznej rzeczywistości (Culler, 2010). 
które ją kształtują, jak imagologia, studia postkolonialne, studia etniczne, studia nad migracją oraz studia traumatologiczne (Hartman, 2015), obejmujące swoim zakresem wszystkich uczestników dramatu. Warto zauważyć, że większość wymienionych tu kierunków badań wyraźnie akcentuje świadomość jeśli nie niestabilności znaczeń, to przynajmniej ich dyskursywnego charakteru ${ }^{5}$ który jest kluczem do dalszej interpretacji.

Takiemu dyskursywnemu, a zarazem ukierunkowanemu na studia kulturowe ujęciu w badaniach literaturoznawczych sekunduje w ostatnim czasie psychologia międzykulturowa. Zwraca ona uwagę na ramy zachowań społecznych determinujące działanie człowieka w kulturze (Matsumoto, Juang: 123-168). Kulturowe cechy, kształtujące sposób myślenia o świecie danej grupy kulturowej, nie tylko warunkują jej przekonania i wartości, ale również emocje, na jakich jej członkowie budują swoje postrzeganie świata (Barnouw, 1985). Co ważne, badania wykazują, że choć same procesy biologiczne warunkujące emocje są wspólne dla wszystkich, to ich ekspresja jest już warunkowana kulturowo. Nie pozostaje to bez wpływu na kategorię zrozumienia w relacjach międzykulturowych.

Świetnie ilustrują to dwa opowiadania Irit Amiel: Naznaczeni oraz Wspótczesny splot. Pierwsze z nich przyjmuje formę trzech wypowiedzi listownych pisanych przez ocalałych z getta Awiszag i Zbyszka oraz polskie małżeństwo Wiktorię i Pawła. W listach bohaterów żydowskich można zaobserwować charakterystyczne napięcie między pragnieniem życia a naznaczeniem śmiercią, między namiętnością a strachem. Żadne z nich nie czuje się u siebie. Poczucie wyobcowania, tak charakterystyczne dla kogoś, kto doświadczył wygnania i utraty, towarzyszy im na każdym kroku. Co więcej, ma ono solidne podstawy w faktach. Kąpielowa Wikcia, która przez całą okupację ukrywa żydowskiego chłopca w norze, wydaje go esbekom, aby nie dopuścić do jego wyjazdu do Ameryki. To, co definiuje bohaterów żydowskich, to właśnie ruch, nieustanne podróżowanie, przemieszczanie się.

Przeciwieństwem Awiszag i Zbyszka są Wiktoria i Paweł, którzy funkcjonują w polskiej ramie zachowań społecznych. Ramę tę wyznacza przede przywiązanie do ziemi, stałość, stabilność, czego wyrazem jest sama profesja Pawła,

5 „Rzeczywistość kulturowa jawi się nam [...] w postaci wiązki przecinających się, poplątanych dyskursów” (Dąbrowski, 2010: 277). 
który jest zdunem. Komin to obraz axis mundi, punkt wyznaczający środek świata, dzielący przestrzeń na swojską i obcą, nasz świat i zaświat. Uprawiany przez Pawła zawód ma jednak znaczeniowo w kontekście Holocaustu drugie dno. Czyszczenie kominów stawia postępowanie Pawła w pewnym podejrzeniu. Kryje się za tym niesformułowane wprost oskarżenie o milczące przyzwolenie Polaków na los żydowskiego narodu. Tę bierną postawę również można tłumaczyć ramami kulturowymi. Wiktoria w liście wyraźnie wskazuje na jej powody: jest nim wychowanie katolickie:

Na ludzi go wychowam, zabiorę na jarmark i do kościoła, i wyrośnie na porządnego katolika. Paweł go nauczy zawodu i życie bendzie jak trzeba. No to co że obrzezany? Pan Jezus też był obrzezany Żydek no i co? Zły katolik był? Same cuda czynił a Żydki go ukrzyżowali.

(Amiel, 1999: 62-63)

Kolejna różnica przebiega na płaszczyźnie tradycja-nowoczesność. Zbyszek jest synem chirurga i nauczycielki hebrajskiego gimnazjum, on sam zostaje artystą, zaś Wiktoria i Paweł wykonują proste rzemieślnicze czynności. Życie tych pierwszych sytuowane jest w mieście, tych drugich pod miastem, na wsi, w otoczeniu królików i kur. Wiążą się z tym określone emocje: u Zbyszka i Awiszag raczej stonowane, naznaczone nostalgią, choć nie obojętne, u Polaków gwałtowne, silne, w których wielka macierzyńska miłość zmienia się w dziką nienawiść.

W drugim z opowiadań Amiel zderza również dwa punkty widzenia: żydowski i niemiecki. Ten pierwszy reprezentują Noemi i jej syn Boaz, drugi narzeczona Boaza, Rut. Ponownie możemy dostrzec w zachowaniach bohaterów żydowskiego pochodzenia to samo napięcie pomiędzy życiem, witalnością, smakowaniem świata i naznaczeniem śmiercią, nawet jeśli to pojawia się tylko w przestrzeni mentalnej. Wyrażają oni emocje: Noemi nienawiść, a Boaz miłość do Rut, w o wiele bardziej wyraźny sposób niż Niemka. Ta skrywa je w sobie, udaje, milczy, jest zdecydowanie bardziej powściągliwa niż jej narzeczony i jego matka. Amiel buduje te postaci, opierając się na profilu psychologicznym danej kultury, który powstaje pod wpływem analizy wyznawanych wartości oraz doświadczeń historycznych kształtujących tożsamość (Boski: 37-407). Richard Lewis, autor modelu międzykulturowego, wyznaczył trzy bieguny kulturowe (linear-active, multi-active i reactive), pomiędzy którymi sytuują się zachowania 
grup etnicznych ${ }^{6}$. W swojej pracy poświęconej ramom zachowań kulturowym określił model właściwy dla kultury Izraela (Lewis: 427-433). Zaliczył do niego: obsesję przetrwania, odwagę, żywotność, wyrażanie poglądów, płynność - zdolność dostosowania się, cierpliwość, moralność i nowoczesność.

Większość tych elementów profilu została wpisana w historie bohaterów opowiadań. Najsilniej daje o sobie znać obsesja przetrwania. Jedenastoletnia dziewczynka przeciskająca się przez deski w komórce, aby uciec z getta; Rafał wypchnięty przez ojca z pociągu zmierzającego do obozu koncentracyjnego, ucieka przed strzelającymi do niego strażnikami albo Daniel, umykający do lasu, gdzie siedzi na drzewie przez całą dobę w obawie przed Niemcami - to tylko najbardziej reprezentatywne przykłady stawania po stronie życia, do czego niewątpliwie trzeba było odwagi. Drugim elementem jest umiejętność dostosowywania się do otaczających warunków. Żydowskie dzieci w nowych warunkach bardzo szybko się asymilują. Rafał zostaje przygarnięty przez parę niemieckich wieśniaków Hansa i Hildę, stając się dla nich jak własny syn; Zbyszek zostaje wychowany przez Wiktora i Pawła, Wiktora „wołał mamo, a Pawła tato”. Chłopiec czuje taką odpowiedzialność wdzięczności, że w liście do ukochanej pisze: „gdyby moja mama była moją prawdziwą matką, to zostałbym w Izraelu i odbił cię twojemu przystojnemu mężowi, ale ponieważ ona nią nie jest i bohatersko mnie ratowała, muszę wrócić” (Amiel: 67). Podobnie znacząca w charakterystyce bohaterów jest ich żywotność, która w opowiadaniach ukazuje się poprzez pełne zanurzenie się w wir życia, co najpełniej egzemplifikuje historia Batii, która „opuszcza dom, swoich troje udanych dzieci i rzuca się w wir Hindu. Z ogoloną na pałę głową - jak wówczas w getcie po tyfusie - w białych, bawełnianych, niemal przezroczystych długich szatach, kolorowych koralach, tańczy z bębenkiem po ulicach miast, śpiewa monotonnie »Hari Kriszna, Hari Rama« [...]. Twierdzi, że jest szczęśliwa” (Amiel: 30). Umiłowanie do życia przejawia także Klara, blondynka o obfitym biuście i zaokrąglonych biodrach, tryskająca hormonami, która za wszelką cenę stara się być kochaną. Nieprzypadkowo żywotność kultury żydowskiej została tu sprzężona z doświadczeniem cielesnym. W Pożegnaniu mojej martwej klasy możemy usłyszeć: „A tu już skaczą

6 Pomijam w tym miejscu prace Edwarda Halla, Geerta Hofstede, Fonsa Trompenaarsa, Charlsa Hampden-Turnera, skupiając się na opublikowanych w 1996 r. badaniach Richarda Lewisa, które obecnie są najczęściej wykorzystywane w teorii relacji międzykulturowych. 
w wodę dziewczyny w toplessach i chłopcy zerkają ukradkiem podnieceni i speszeni, a dziewczynki myślą, że wkrótce też będą miały takie śliczne zgrabne cycuszki [...]. A potem wypoczywają, leżąc na błękitnych leżakach, w jednym rzędzie z opalonymi, wysportowanymi wnukami” (Amiel: 83). Doświadczenie cielesności w jej najbardziej biologicznym, często atawistycznym sensie, jest namiastką potwierdzenia, że pozostało się wśród żywych. Ciało piękne, zdolne do uprawiania miłości, nagie, będące zapowiedzią rozkoszy jest dowodem życia. Jest czymś odległym od ciał zagazowanych, wdeptanych w obozowe błoto czy wyniszczonych głodem lub medycznymi eksperymentami. Świetnie ilustruje to poniższy fragment opowiadania Naznaczeni:

I chodziłaś tam bezbronna między pawilonami waliz, włosów, protez, szczoteczek do zębów i wyłaś w sobie bezgłośnie koło dziecinnej sukienki ze zrudziałą plamą krwi. Wróciłaś późną deszczową nocą, w wigilię Jom Kipur, zziębnięta, ociekająca wodą od stóp do głów, szczękająca zębami, a ja wycierałem twoje fantastyczne ciało suchymi ręcznikami i ogrzewałem twoje skostniałe stopy moim gorącym oddechem.

(Amiel, 1999: 66).

Bohaterowie Amiel nie tylko są zdolni do wyrażania poglądów, ale wręcz je manifestują, szczególnie gdy sprawa dotyka ich egzystencji. Noemi we Wspótczesnym slocie wypomina synowi: „A teraz ty, ty, co nosisz imię mego ojca, którego oni w twoim wieku zadusili gazem w Treblince, ty chcesz pojąć za żonę kobietę, z ich plemienia i przynieść na świat dzieci, moje wnuki z ich genami, dzieci, w których żyłach popłynie krew morderców twego dziadka?" (Amiel: 73). Albo Ziwa - robiąca karierę na uniwersytecie jako znawca literatury, która po pięćdziesięciu latach odnajduje matkę. Uratowana w czasie wojny przez siostry zakonne, nic nie wiedząc o swojej rodzinie, zastanawia się nad brakiem kontaktu ze strony matki. Żadnych poszukiwań, żadnego listu. Swój pogląd wyraża w najbardziej z możliwych drastyczny sposób - samobójstwem.

Z tym ostatnim wiąże się kategoria odwagi, o której Amiel niejednokrotnie pisze. W odniesieniu do Linki, osiemnastoletniej bohaterki opowiadania, pisze: „Wówczas podziwiałam jej odwagę w wyborze śmierci, dziś zdaję sobie sprawę, że trzeba było o całe niebo większej odwagi, aby wybrać życie” (Amiel: 12). Takie właśnie wybory dokumentuje w swoich opowieściach autorka. 
W opisach poszczególnych bohaterów (może już w mniejszym stopniu) pojawiają się pozostałe wartości: moralność (historia Rafała, którego syn spłodzony z Hildą jeszcze w Niemczech ginie w wypadku razem z synem zrodzonym z żony Niry, Sefardyjki, już w Izraelu) czy cierpliwość w znoszeniu cierpienia.

Lewis zwraca uwagę, że nie można wyobrazić sobie tego profilu bez odniesienia do religii. Judaizm jest podstawowym czynnikiem tożsamościowym tego narodu i kultury. I rzeczywiście u Amiel takich odniesień jest naprawdę sporo. Każde ocalenie ma wymiar mesjański. Wrogowie naznaczeni są poprzez biblijny Edom, wielokulturowa Palestyna przez metaforę wieży Babel, większość historii ma swoje odniesienie do Tory i ksiąg prorockich Izajasza, Daniela, Jeremiasza czy Hioba. Jak mówi Gidi, bohaterka Izraelskiego tygla: „My przyszliśmy na świat z morza, z pustyni, z samej Biblii” (Amiel: 89).

Drugim czynnikiem jest historia, a szczególnie wiek XX, w którym dokonał się Holocaust. Pamięć o Shoah jest dla współczesnego Izraela konstytutywnym elementem tożsamościowym. I właściwie każde opowiadanie dotyka tego doświadczenia, pokazując, że dzisiaj być Żydem, to być ocalonym. Trzecim wydaje się idea państwowości, powstania po dwu tysiącach lat państwa Izrael, jego niezależności politycznej i zaznaczenia odrębności wobec świata arabskiego - swego miejsca w Palestynie. Trudnością w określaniu profilu może być jednak dość duże rozproszenie Żydów i ich spolonizowanie, zruszczenie czy zamerykanizowanie, jakiego doświadczyli z powodu swojej historii, o czym wielokrotnie, jak choćby w Izraelskim tyglu, wspomina Amiel. Bohaterowie jej opowiadań przyjeżdżają do Palestyny z różnych stron, często - jak Elkana wymyślają swoją biografię, by bardziej wpisać się w nową ojczyznę. Uczą się hebrajskiego, bo dotąd posługiwali się językami „obcych”.

W zaproponowanym przez Lewisa profilu kulturowym Izrael znajduje się niemal w środku między dwoma silnymi modelami: linearnym i multikatywnym, w niewielkim stopniu zbliżając się do kultury liniowej (Lewis: 29-31). Wynikający z tego profilu model żydowskiej komunikacji wskazuje na tendencję do zajmowania silnych pozycji w rozmowie, posługiwania się logiką i ogromną erudycją (przypomnijmy chociażby postać Ziwy), przy jednoczesnym uciekaniu się do humoru. Pomimo zajmowania jednoznacznych stanowisk, komunikacja żydowska jest cywilizacją sporu, która wyrasta z doświadczenia talmudycznego. 
Wątek ten wydaje się dość istotny dla podjętej tu problematyki punktów widzenia i dyskursywności proponowanej w opowiadaniach Irit Amiel, dlatego warto się przy nim na chwilę zatrzymać. Konstanty Gebert pisze, że „Talmud jest zapisem sporów”, jest zbiorem interpretacji Tory, a te nigdy nie są ustalone raz na zawsze, bowiem są zależne od osobistego rozeznania i doświadczenia. Cytując Gersonidesa, pisze:

Każdy, kto studiuje nasz Talmud, wie, że gdy nasi komentatorzy spierają się o coś, żaden nie ma absolutnych dowodów na poparcie swojego stanowiska, choćby nie wiem, ile trudności potrafił sprawić swemu przeciwnikowi. Przedmiotem naszych badań nie jest prosta matematyka, w której możliwe jest tylko jedno rozwiązanie. W każdej debacie talmudycznej poświęcamy cała naszą siłę i moc, by odrzucić, za pomocą logicznych dowodów, jeden pogląd na korzyść drugiego. Następnie w tym świetle interpretujemy wszystkie orzeczenia, czasem w sposób wymuszony. Ostatecznie aprobujemy ten obraz w całości, który wydaje się najłatwiejszy do przyjęcia przy uwzględnieniu wszystkich danych.

(Gebert, 2004: 121)

Zaproponowana powyżej perspektywa dyskursywna jest dla człowieka wychowanego w kulturze greckiej, w kulcie Logosu, który zakłada dotarcie do sensu poprzez odrzucanie fałszywych przekonań, czymś dramatycznie niezrozumiałym. Egzemplifikacją takiej postawy jest model kultury liniowej, który domaga się jednoznacznych odpowiedzi opartych na myśleniu asercyjnym, wykluczającym dialektyczne aporie. Tradycja żydowska zakłada coś przeciwnego - rozbieżności i spory, które nie tylko się nie wykluczają, ale właśnie uzupełniają w drodze ku prawdzie.

Wywiedzioną z tradycji żydowskiej „cywilizację sporu” można z powodzeniem odnieść do kategorii dyskursywności. Można ją rozumieć poprzez Lévinasowską koncepcję spotkania z Innym. Dyskurs uobecnia Innego, którego pojawienie się jest wydarzeniem, a zarazem wyzwaniem dla Samego-Siebie ukształtowanego w konkretnych ramach kultury. Inny zawsze pozostaje w opozycji do wspólnotowości istnienia, do zbiorowości wytwarzającej określone znaczenia. Dlatego dyskurs wydobywa różnicę, nie-tożsamość z językiem spójnej ramy kulturowej. Stawia Samego-Siebie wobec prawdy o nim, wobec czego może on zająć dwie postawy: pierwsza to zwarcie pozytywnych podmiotów wartości, rzeczników prawa i ładu moralnego i poszukiwanie momentu porozumienia; druga to intryga zła, które przeciwstawia sobie i zmusza do walki (Tischner: 
89-96), ta zaś może skończyć się albo przyjęciem racji Innego, albo usprawiedliwieniem siebie. Dlatego dyskurs nigdy nie jest neutralny etycznie, zawsze niesie jakąś miarę moralną. Szczególnie jeśli wziąć pod uwagę doświadczenie Holocaustu i relacji między Żydami, Polakami i Niemcami nie tylko w czasie wojny, ale i przed nią. Przywoływany już wcześniej Jan Błoński w początkowym fragmencie książki Biedni Polacy patrzą na getto dotyka właśnie problemu zrozumienia (czy właściwie niezrozumienia) w kontekście Innego. Pisze:

Żyd to Inny, inny par excellence i dlatego polsko-żydowskie porozumienia i nieporozumienia skupiają w sobie mnóstwo problemów, religijnych, moralnych, psychologicznych, prawnych, społecznych w i końcu także politycznych.

(Błoński, 1994: 5)

Na tej uwadze zasadza się koncepcja opowiadania Wspótczesny splot. Noemi poznaje w czasie świąt narzeczoną swojego syna Boaza - Rut. Z początku myśli, że dziewczyna jest Dunką - ze względu na jasne, proste włosy. Patrząc na zakochaną parę, czuje się szczęśliwa. Gdy dziewczyna zdradza swoje niemieckie pochodzenie, Noemi doznaje wstrząsu:

A mnie zrobiło się ciemno przed oczami, cała krew odpłynęła mi z mózgu i nie upadłam tylko dzięki temu, że mój Jeremi schwycił mnie za rękę i podparł w ostatniej chwili. Bo stanął przede mną jak żywy ten piekielny esesman z naszego obozu - Günter z Wupertallu.

(Amiel, 1999: 71).

Zderzenie z prawdą Innego wywołuje w niej bunt, prowokuje do walki, rodzi nieakceptację. Ale Amiel nie pozostaje tylko przy tej perspektywie. Pozwala spojrzeć na to spotkanie oczami Boaza i Rut. Dla syna ocalonej kobiety Boaza - Rut jest takim właśnie ocaleniem. Z życia, które prowadził, pełnego szaleństwa, narkotyków, beztroski, wyrywa go autentyczność tej dziewczyny, jej prostota, prawdziwość, a zarazem obcość. Spotkanie z Innym staje się dla Boaza wezwaniem do poszukiwania zrozumienia samego siebie, a poprzez to - do wyzwolenia spod wpływu matki i jej historii. Z jeszcze innego punktu widzenia patrzy na Rut, która ma świadomość, że ciąży na niej „łapa historii”, że jej przynależność rodowa i historyczna determinuje jej jednostkowy los. Dziewczyna przyjmuje rację Innego - Noemi - i odchodzi od Boaza, wyjeżdża. Jak mówi: „nagle rozumiem lepiej Żydów i identyfikuję się z tym narodem, 
który przez dwa tysiące lat dźwiga na swoich barkach brzemię jakiegoś mitologicznego grzechu swoich praszczurów" (Amiel: 76). I Rut trafia chyba w samo sedno osmalenia, o którym pisze Amiel. Bycie Żydem oznacza bowiem być osmalonym, naznaczonym blizną czy to w postaci tatuażu, o którym wspomina Noemi, czy w formie traumy, która nie pozwala zmrużyć oka.

Powołując się na Benveniste’a, Mieczysław Dąbrowski wskazuje na podstawową funkcję dyskursu wobec historii. Polega ona na nałożeniu na opowiadaną historię określonego punktu widzenia „ja-ty-tu-teraz”. Mówiąc inaczej, „dyskurs ujawnia w niezwykle silnym stopniu komunikacyjne usytuowanie i nastawienie piszącego/mówiącego, ustanawiając pewien jego modus i idiom, jest swoiście rozumianym dialogiem społecznym” (Dąbrowski, 2009: 12). Przyjęcie tej subiektywnej perspektywy, jak dowodzi teoria kognitywna (Langacker, 2000), wiąże się z dwoma sposobami konstruowania sceny wydarzeń: obiektywnym, który zawiera się w języku, kodzie i jest warunkowany przez ramy kulturowe, i subiektywnym, silnie zależnym od osobistego doświadczenia. Napięcie pomiędzy nimi może warunkować pojawienie się postaci wchodzących w role uczestników dyskursu. Tak dzieje się w przywołanym już opowiadaniu Wspótczesny splot. Amiel buduje dramat rozpisany na role: Noemi - ocalałej z Holocaustu Żydówki, jej syna - Boaza i jego dziewczyny - Rut.

W początkowym fragmencie Noemi wywołuje obraz Rut, pięknej dziewczyny, szczęśliwej, radosnej, bo kojarzonej z narodowością duńską i królem Danii, który nie pozwolił wywieźć Żydów, ale odesłał ich promem do Szwecji. Z czasem rozpoznaje w niej Niemkę i wcześniejszy wizerunek zmienia się w obraz esesmana z obozu, a Rut staje się współwinną spadkobierczynią morderców. W opowieści Noemi pojawia się także syn, zakochany i szczęśliwy, pochłonięty światem i stojący bardziej po stronie żywych niż umarłych (w przeciwieństwie do matki). Amiel dopuszcza do głosu wywołane opowieścią postaci: najpierw Boaza, a na końcu Rut. Są one odpowiedzią na postawę Noemi i w jakiś sposób kontrapunktem etycznym dla reprezentowanego przez nią stanowiska.

W podobny sposób skomponowane są opowiadania: Naznaczeni, którego historia zostaje opowiedziana za pomocą trzech listów, czy Izraelski tygiel, rozpisany na głosy budowniczych nowego państwa. Można zauważyć, że u Amiel mamy do czynienia z dwoma (a czasem więcej) współwystępującymi punktami widzenia. Czytelnik jest postawiony w pozycji bohatera utworu, jednak punkt 
ten zmienia się wraz z wchodzeniem na scenę kolejnych osób, reprezentujących inny kulturowo, historycznie i egzystencjalnie punkt widzenia (Noemi - Boaz - Rut; Awiszag - Wiktora i Paweł - Zbyszek; Elana - Gidi - Amalia). Korelacja tych sprzecznych punktów widzenia zmusza czytelnika do szybkiego przechodzenia między nimi, a co za tym idzie - między ramami kulturowymi, które je warunkują. W efekcie prowadzi to do współwystępowania w świadomości odbiorcy kilku punktów widzenia w ramach tego samego oglądu i jednoczesnego przyjęcia dwóch (lub więcej) z nich. W ten sposób ujawniałaby się dyskursywność narracji opowiadań Amiel.

Kluczowy zatem dla tych rozważań wydaje się punkt widzenia, w którym skupiają się dwa silne elementy kultury żydowskiej i osobistego doświadczenia: talmudyczna „cywilizacja sporu” i trauma Holocaustu. Punkt widzenia, obok orientacji, kierunkowości i stopnia uprzedmiotowienia elementów konceptualizacji, jest aspektem perspektywy - jednym z sześciu wymiarów obrazowania. Wymienione powyżej aspekty wskazują na silne powiązanie punktu widzenia z przestrzenią i odległością podmiotu od opisywanego obiektu. Zgodnie z tym rozpoznaniem wyróżnia się cztery stopnie zależności przestrzennej: od najbardziej subiektywnego, w którym punkt widzenia umieszczony jest niemal w obiekcie opisywanym, do obiektywnego, który przypomina „oko Boga”. Dla opowiadań Irit Amiel najbardziej interesującym będzie właśnie ów subiektywny punkt widzenia.

Najbardziej oczywiste w tym kontekście wydaje się przywołanie opowiadania inicjującego zbiór - Kartka z pamiętnika. Narracja prowadzona jest pierwszoosobowo z charakterystycznym dla relacji pamiętnikarskiej przesunięciem czasowym. Bohaterka, jedenastoletnia dziewczyna (alter ego Irit Amiel) wspomina swoją ucieczkę z getta w 1942 roku, co potwierdza biografia pisarki. Używa do tego narracji subiektywnej, pokazując świat z bardzo bliskiej odległości; czytelnik widzi konkretne szczegóły, przedmioty, fragmenty, nie potrafi jednak zbudować sobie wyobrażenia całości otaczającej bohaterkę przestrzeni. Z całej przeprawy dziewczynka zapamiętuje żółty płaszczyk, skórkę od chleba, którą matka daje jej na pożegnanie, drewnianą bramę, zwitek zielonych

\footnotetext{
7 Obok perspektywy Langacker wymienia jeszcze: skalę i zakres predykacji, relację profilbaza, stopień ukonkretnienia, względne wyróżnienie podstruktur predykacji i interpretację w zależności od założeń i oczekiwań (Langacker 1995: 19-23.)
} 
banknotów, dziurę i pozłacany obraz czarnej Matki Boskiej Częstochowskiej. „Dzieciństwo, berecik, szalik, moja śliczna mama i mój ukochany łysy tatuś, wszystko to pozostało na zawsze po tamtej stronie" (Amiel: 9).

Autorka często zmienia punkty widzenia w swojej narracji, wprowadzając albo formę listu, albo relacji z pierwszej ręki, albo wreszcie posiłkując się wyimaginowaną historią, ale zawsze stara się maksymalnie zbliżyć do opisywanej postaci. Świetnie ilustruje to Linka, opowiadanie o osiemnastoletniej dziewczynie popełniającej samobójstwo zaraz po wyjściu z obozu uchodźców w 1945 roku. Narrator od samego początku sekunduje bohaterce: „Linka bardzo wcześnie zrozumiała, że po tym, co się stało, nie będzie można dalej żyć. Zrozumiała to dużo wcześniej niż inni, mądrzejsi i starsi od niej [...] i bez zwłoki popełniła samobójstwo" (Amiel: 10). Dopuszcza do głosu jej wybór. Snując wyimaginowaną biografię Linki, zmienia punkt widzenia:

Ale to wszystko się nie zdarzyło i Linka pozostała w niemieckim zimnym błocie, więc nie musi się teraz obawiać, że mąż dostanie zawału, wnuk będzie służył w Libanie, a ona sama zachoruje na jedną z tych strasznych, starczych chorób Alzheimera czy Parkinsona.

(Amiel, 1999: 11)

W przywołanym opowiadaniu jedynie pozornie dokonuje się przesunięcie punktu widzenia. Od początku bowiem, co dokonuje się na poziomie języka i stylu (poprzez ironię), próbujemy zrozumieć postać Linki z perspektywy życia - punktu widzenia, który ustawia narrator. Zresztą ironia staje się w rękach narratora narzędziem eliminowania tychże punktów. W Palestyńczyku czytamy o młodzieńcu, którego narratorka poznaje w obozie dipisów w Niemczech. Bohater Jest zdeterminowany, by dostać się do Palestyny, bierze dział w wojnie jw obronie swojego kraju, buduje kibuc, angażuje się w sprawy wolnościowe.

Kilka lat później, latem 1989 roku, Palestyńczyk wsiadł do autobusu jadącego do Jerozolimy, który zrzucił w przepaść palestyński Arab-terrorysta. I nasz prawy, odważny Palestyńczyk, który walczył o prawa arabskich Palestyńczyków do własnego państwa, zginął z ich rąk w krwawym autobusie, na drodze do Jerozolimy.

(Amiel, 1999: 26) 
Ironia tragiczna demaskuje u Amiel fałszywe punkty widzenia. Sprowadza wszystkie ujęcia do jednego wspólnego mianownika, do tego, co wspólnotowe w tym doświadczeniu, do naznaczenia śmiercią.

Czy ta zmienność punktów widzenia pozwala zrozumieć, co boli „osmalonych”? Czy pozwala szczerze odpowiedzieć na pytanie Borysa: „Czy ty mnie kochasz?”, bo na deficyt miłości cierpią wszyscy bohaterowie opowiadań Amiel? Wreszcie, czy to spotkanie z Innym, także w perspektywie kulturowej różnorodności, pozwala przejść od Samego-Siebie do Drugiego i przyjąć jego perspektywę? Wydaje się, że tak. Opowiadania Amiel, ukazujące jednostkowe historie tak szczerze i bezkompromisowo, są zaproszeniem do „wejścia w czyjeś buty” i przejścia w nich parę kroków, zanim wyda się wyrok.

\section{Bibliografia}

Amiel, Irit. Osmaleni. Izabelin: Izabelin Studio, 1999.

Barker, Chris. Studia kulturowe. Teoria i praktyka. Tłum. Agata Sadza. Kraków: Wydawnictwo Uniwersytetu Jagiellońskiego, 2005.

Barnouw, Victor. Culture and Personality. Dorsey: Homewood, 1985.

Błoński, Jan. Biedni Polacy patrza na getto. Kraków: Wydawnictwo Literackie, 1994.

Boski, Paweł. Kulturowe ramy zachowań spotecznych. Warszawa: Wydawnictwo Naukowe PWN, 2010.

Culler, Jonathan. „Uprawianie badań kulturowych”. Tłum. Maciej Maryl. Teksty Drugie 5 (2010): 97-109.

Dąbrowski, Mieczysław. Komparatystyka dyskursu. Dyskurs komparatystyki. Warszawa: Dom Wydawniczy Elipsa, 2009.

------. „Komparatystyka kulturowa”. Komparatystyka dla humanistów. Red. Mieczysław Dąbrowski. Warszawa: Wydawnictwo Uniwersytetu Warszawskiego, 2010. 211-288.

Hartman, Geoffrey H. „Wiedza traumatyczna i badania literackie”. Tłum. Jan Burzyński. Antologia studiów nad traumą. Red. Tomasz łysak. Kraków: Universitas, 2015. 377-414.

Gebert, Konstanty. 54 komentarze do Tory. Kraków: Austeria, 2004. 
Głowiński, Michał. „Posłowie”. Irit Amiel. Osmaleni. Izabelin: Izabelin Studio, 1999. 103-109.

Langacker, Ronald. Grammar and Conceptualization. Berlin: Mouton de Gruyter, 2000.

-----. Wyktady z gramatyki kognitywnej. Kazimierz nad Wista, grudzień 1993. Red. Henryk Kardela, Lublin: Wydawnictwo UMCS, 1995.

Leociak, Jacek. Tekst wobec Zagtady (o relacjach z getta warszawskiego). Wrocław: Wydawnictwo Leopoldinum, 1997.

Lewis, Richard. When Cultures Collide. Leading across Cultures. London-Boston: Nicholas Brealey International, 2006.

Maryl, Maciej. „Sztuka czytania? Mieke Bal w teorii i w praktyce”. Teksty Drugie 4 (2013): 312-326.

Matsumoto, David, Linda Juang. Psychologia międzykulturowa. Tłum. Agnieszka Nowak. Gdańsk: Gdańskie Wydawnictwo Psychologiczne, 2007.

Pratt, Mary Louis. Imperial Eyes. Travel Writing and Transculturation. New York: Routledge, 1992.

Skarga, Barbara. Ślad i obecność. Warszawa: Wydawnictwo Naukowe PWN, 2002.

Tischner, Józef. Filozofia dramatu. Kraków: Znak, 1998.

\section{Point of View of the Other, An Analysis of Stories by Irit Amiel in the Context of Intelectual Psychology}

\section{Summary}

Intercultural psychlogy is a discipline within cultural studies. It is of an interdisciplinary character, combining the philosophy of meeting, imagology, and discourse and becomes the part of the metadiscourse practiced by cultural comparative studies. The article attempts to test the tool in reading Irit Amiel's stories. The author is an Israeli writer who, in The Seared, deals with the topic of the Holocaust. Her biography - Jewish in origin, with her childhood in Poland, and wandering around Germany and Italy, finally stopping in a Palestinian haven - testifies to her intercultural pedigree. Amiel takes up the subject of the Holocaust after almost fifty years of silence, and she does so by showing different cultural points of view. Intercultural psychology discovers the 
framework of social behavior in which the characters move. This tool allows us to show that today "being seared" is one of the constitutive features of the Jewish culture.

Keywords: intercultural psychology, discourse, philosophy of dialogue, Irit Amiel, Shoah

Słowa kluczowe: psychologia międzykulturowa, dyskurs, filozofia dialogu, Irit Amiel, Szoah 